\title{
NILAI TAMBAH SNACK SAYURAN ORGANIK UD JIBARIZ DI KECAMATAN GETASAN KABUPATEN SEMARANG
}

\author{
(Value Added Home Industry Snack Organic Vegetables UD Jibariz in Getasan, District \\ Semarang)
}

\section{Maria Mega Mawarni dan Maria}

Fakultas Pertanian dan Bisnis, Universitas Kristen Satya Wacana Salatiga

J1. Diponegoro 52-60 Salatiga 50771, Jawa Tengah-Indonesia

Penulis koresponden : $522015601 @$ student.uksw.edu

Article Submitted: 19-05-2021

Article Accepted: 03-08-2021

\begin{abstract}
Home industry Jibariz is one of the SMEs that processes organic vegetable products into sticks and dumplings. The purpose of the study was to determine the amount of added value generated, analyze costs, revenues, profits from processing, and business developments from the trend of selling Jibariz organic vegetable snacks 2 years before $(2018,2019)$ and during the Covid-19 pandemic (2020). This research was conducted in Jampelan hamlet, Getasan subdistrict, Semarang district. Sampling was done intentionally (purposive sampling). The data was processed using quantitative descriptive methods. Analysis of the data used in this study is the analysis of added value using the Hayami method. The result of the research shows that the added value of Jibariz organic vegetable snack is Rp. 61,800 per kilogram or $68.66 \%$ of the product value. The average cost incurred each month is Rp. 3,557,556 with a total production of 600 packs per month and able to provide a monthly income of Rp. 9,000,000 and the profit earned is $\mathrm{Rp}$. 3,181,000. The value of the $\mathrm{R} / \mathrm{C}$ ratio obtained is 1.5 so it is feasible to continue. The development of Jibariz's organic vegetable snack business in the 2 years before Covid-19 the sales trend fell, while in 2020 during the Covid-19 pandemic the sales trend increased.
\end{abstract}

Keywords: Organic Vegetables, Added Value, Sales Volume, R/C Ratio

\section{PENDAHULUAN}

Kesadaran masyarakat lambat laun semakin terbuka terhadap risiko bahan pangan yang mengandung pestisida sintetis seperti sayuran konvensional yang berdampak pada gangguan kesehatan akibat dari paparan residu kimia. Tingginya kesadaran masyarakat akan hidup sehat membuat mereka beralih pada sayuran organik. Sayuran organik merupakan sayuran yang dibudidayakan menggunakan bahan-bahan alami tanpa kimia sintetis berbahaya sehingga ramah lingkungan. Sayuran organik tersebut mengandung cita rasa tinggi, banyak vitamin, dan bebas dari bahan kimia. Menurut Ellyas (2008), hasil produksi sayur organik merupakan hasil dari pertanian yang berpedoman pada sistem budidaya pertanian organik yang tidak menggunakan pupuk kimia sintetis, pestisida sintetis, rekayasa genetika, serta zat pengatur tumbuh. Kegiatan pertanian dilakukan dengan mengandalkan tenaga manusia, memanfaatkan bahan-bahan alami, dan limbah organik ternak.

Kabupaten Semarang mempunyai luas wilayah sebesar 95.020,674 Ha dengan $64 \%$ wilayah tersebut adalah lahan pertanian dan sisanya lahan non pertanian. Home industry snack sayuran organik Jibariz terletak di dusun Jampelan, kecamatan Getasan, kabupaten Semarang, provinsi 
Jawa Tengah. Kecamatan Getasan merupakan kawasan petani yang memproduksi hortikultura. Tanaman hortikultura merupakan komoditas yang tidak tahan lama (cepat busuk). Pada saat panen raya seringkali terjadi penurunan harga sehingga merugikan petani. Solusi yang perlu dilakukan adalah meningkatkan kreativitas dalam pengolahan hasil sayuran organik sehingga dapat meningkatkan nilai tambah.

Home industry snack sayuran organik Jibariz adalah salah satu UKM yang berdiri pada tahun 2011, dikelola oleh ibu Sudaryanti. Produk yang dihasilkan adalah stik dan pangsit dengan berbagai varian rasa antara lain stik wortel, stik labu, stik jagung manis, stik kentang pedas, stik bayam, stik seledri, stik brokoli, stik ubi ungu, pangsit labu, pangsit jagung manis, pangsit adas, dan pangsit daun singkong.Teknologi yang digunakan dalam pengolahan ini masih bersifat sederhana yaitu menggunakan mesin giling adonan dan alat pemotong adonan secara manual. Dalam proses produksi terdapat 2 orang sebagai tenaga kerja. Pada awal usaha produksi yang dihasilkan hanya sekitar 1-2 kg per hari, seiring berkembangnya usaha produksi mencapai 10-20 kg per hari. Pada saat ini produksi yang dihasilkan dalam satu bulan rata-rata 500-600 bungkus dengan berat bersih per bungkus sebesar 250 gram.

Dalam mencapai target usaha agar semakin berkembang dan dikenal oleh banyak kalangan masyarakat, serta mendobrak pangsa pasar maka dilakukan kegiatan promosi yaitu melalui media sosial seperti facebook, blogspot, selain itu juga memasang spanduk dan membagikan brosur. Pengenalan produk juga dilakukan secara langsung yaitu dengan cara memasang stand-stand khusus pada momen-momen tertentu. Pemasaran saat ini telah menjangkau di berbagai wilayah seperti Kopeng, Salatiga, Semarang, Magelang, Yogjakarta, Solo, Surabaya, dan Jakarta.
Pada saat ini telah memasuki era industri ekonomi kreatif yang memicu SDM dalam mengandalkan kreativitas dan inovasi dalam mengolah produk. UMKM merupakan usaha yang membutuhkan banyak tenaga, akan tetapi tidak memerlukan persyaratan spesifik dan teknologi masih bersifat sederhana sehingga modal yang dikeluarkan relatif sedikit. Berdasarkan latar belakang dan permasalahan diatas, maka tujuan dari penelitian ini adalah (1). Mengetahui besaran nilai tambah yang diciptakan ; (2). Mengetahui besaran biaya, penerimaan, keuntungan, $\mathrm{R} / \mathrm{C}$ ratio serta mengetahui trend perkembangan usaha pada home industry snack sayuran organik Jibariz 2 tahun sebelum dan saat pandemi Covid-19.

\section{METODE PENELITIAN}

Tempat dan waktu penelitian dilakukan di dusun Jampelan, kecamatan Getasan, provinsi Jawa Tengah pada bulan September 2020. Metode purposive sampling digunakan dalam pengambilan sample dengan kriteria-kriteria tertentu, untuk menggali informasi sesuai dengan tujuan penelitian. Terdapat 6 orang responden pada penelitian ini diantaranya, 1 orang responden yaitu pemilik usaha home industry snack sayuran organik Jibariz dan 5 orang konsumen. Data-data yang dikumpulkan diperoleh dari hasil wawancara dengan pemilik usaha snack sayuran organik Jibariz sebagai informan, dan lima orang konsumen sebagai responden. Penggolahan data menggunakan metode deskriptif kuantitatif. Deskriptif menjelaskan kondisi umum terkait objek penelitian dari hasil analisis data yang diperoleh (Sugiyono, 2014). Analisis kuantitatif menggunakan prosedur-prosedur statistik sehingga memperoleh penemuan yang hendak dicapai (Sujarweni, 2014). Analisis data yang digunakan antara lain besaran nilai tambah, total biaya yang dikeluarkan, penerimaan kotor, keuntungan bersih, nilai $\mathrm{R} / \mathrm{C}$ ratio, dan trend 
perkembangan usaha 2 tahun sebelum dan saat pandemi Covid-19. Analisis nilai tambah pada home industry snack sayuran organik Jibariz diolah dengan metode Hayami. Perhitungan dilakukan menurut satuan bahan baku utama pada hasil output produk (Hayami, 1987). Tabel 1 merupakan langkah-langkah menghitung nilai tambah dengan menggunakan metode Hayami.

Tabel 1. Perhitungan Analisis Nilai Tambah

\begin{tabular}{|c|c|c|}
\hline No. & Keterangan & \multirow{2}{*}{ Notasi } \\
\hline & Input, Output dan Harga & \\
\hline 1. & Hasil Produksi : stik dan pangsit (Kg/Hari) & $\mathrm{A}$ \\
\hline 2. & Bahan Baku : tepung terigu $(\mathrm{Kg} / \mathrm{Hari})$ & $\mathrm{B}$ \\
\hline 3. & Tenaga Kerja (Jam/Hari) & $\mathrm{C}$ \\
\hline 4. & Faktor Konversi $(1 / 2)$ & $\mathrm{d}=\mathrm{a} / \mathrm{b}$ \\
\hline 5. & Koefisien Tenaga Kerja (3/2) & $\mathrm{e}=\mathrm{c} / \mathrm{b}$ \\
\hline 6. & Harga Snack Jibariz $(\mathrm{Rp} / \mathrm{Kg})$ & $\mathrm{F}$ \\
\hline \multirow[t]{2}{*}{7.} & Upah Rata-Rata (Rp/hari) & $\mathrm{G}$ \\
\hline & Pendapatan dan Keuntungan & \\
\hline 8. & Harga Bahan Baku: tepung terigu $(\mathrm{Rp} / \mathrm{Kg})$ & $\mathrm{H}$ \\
\hline 9. & Sumbangan Input Lain $(\mathrm{Rp} / \mathrm{Kg})$ & I \\
\hline 10. & Nilai Produksi Snack Jibariz (Rp/Kg) & $\mathrm{j}=\mathrm{dxf}$ \\
\hline \multirow[t]{2}{*}{11.} & a. Nilai Tambah $(\mathrm{Rp} / \mathrm{Kg})$ & $k=j-h-i$ \\
\hline & b. Ratio Nilai Tambah (\%) & $\mathrm{l}=(\mathrm{k} / \mathrm{j}) \times 100 \%$ \\
\hline \multirow[t]{2}{*}{12.} & a. Imbalan Tenaga Kerja $(\mathrm{Rp} / \mathrm{Kg})$ & $\mathrm{m}=\mathrm{exg}$ \\
\hline & b. Bagian Tenaga Kerja (\%) & $\mathrm{n}=(\mathrm{m} / \mathrm{k}) \times 100 \%$ \\
\hline \multirow[t]{3}{*}{13.} & a. Keuntungan (11a-12a) & $\mathrm{o}=\mathrm{k}-\mathrm{m}$ \\
\hline & b. Tingkat Keuntungan $(\%)$ & $\mathrm{p}=(\mathrm{o} / \mathrm{k}) \times 100 \%$ \\
\hline & Balas Jasa untuk Faktor Produksi & \\
\hline \multirow[t]{4}{*}{14.} & Marjin & $q=j-h$ \\
\hline & a. Pendapatan Tenaga Kerja (\%) & $\mathrm{r}=(\mathrm{m} / \mathrm{q}) \times 100 \%$ \\
\hline & b. Sumbangan input lain (\%) & $\mathrm{s}=(\mathrm{i} / \mathrm{l}) \times 100 \%$ \\
\hline & c. Keuntungan $(\%)$ & $\mathrm{t}=(\mathrm{o} / \mathrm{q}) \times 100 \%$ \\
\hline
\end{tabular}

Sumber : Hayami, 1987 adalah :

Analisis lain yang digunakan peneliti

\section{Biaya Total}

Biaya total diperoleh dari hasil penjumlahan antara biaya tetap dan biaya variabel (Boediono, 2002). Dapat dihitung menggunakan rumus sebagai berikut :

Dimana :

$$
\mathbf{T C}=\mathbf{T F C}+\mathbf{T V C}
$$

$\mathrm{TC}=$ Total biaya $(\mathrm{Rp} / \mathrm{bulan})$

TFC $=$ Total biaya tetap/penyusutan

(Rp/bulan)
TVC $=$ Total biaya variabel $(\mathrm{Rp} / \mathrm{bulan})$

\section{Penerimaan}

Menurut Ambarsari, et all (2014), penerimaan merupakan hasil perkalian antara total produk yang dihasilkan dengan harga dari produk tersebut. Dapat dihitung menggunakan rumus sebagai berikut:

Dimana :

$$
\mathbf{T R}=\mathbf{P} \times \mathbf{Q}
$$

$\mathrm{TR}=$ Total penerimaan $(\mathrm{Rp} / \mathrm{bulan})$

$\mathrm{Q}=$ Harga produk (Bungkus/bulan) 


\section{Keuntungan}

Keuntungan merupakan selisih dari penerimaan kotor dengan total biaya produksi (Soekartawati, 2003). Dapat dihitung menggunakan rumus sebagai berikut :

Dimana :

$$
\Pi=\text { TR-TC }
$$

$\Pi=$ Pendapatan bersih (Rp/bulan)

$\mathrm{TR}=$ Penerimaan kotor (Rp/bulan)

$\mathrm{TC}=$ Total biaya produksi $(\mathrm{Rp} / \mathrm{bulan})$

\section{Efisiensi Usaha}

Nilai R/C ratio diperoleh dari pendapatan kotor yang diterima dalam setiap rupiah yang digunakan dalam setiap produksi, dan menunjukan keadaan suatu usaha yang dijalankan. $\mathrm{R} / \mathrm{C}$ ratio digunakan untuk perbandingan penerimaan dengan total biaya (Suratiyah, 2015). Dapat dihitung dengan menggunakan rumus sebagai berikut :

$$
\mathrm{R} / \mathrm{C} \text { ratio }=\frac{T R}{T C}
$$

Kriteria hasil ratio sebagai berikut :

$\mathrm{R} / \mathrm{C}>1$, usaha efisien/layak diusahakan

$\mathrm{R} / \mathrm{C}=1$, usaha impas/ tidak untung dan tidak rugi

$\mathrm{R} / \mathrm{C}<1$, usaha tidak efisien/tidak menguntungkan

\section{HASIL DAN PEMBAHASAN}

Menurut Husniah, et all (2019), pengolahan komoditas sayuran dilakukan untuk meningkatkan nilai tambah serta menaikkan harga jual produk (olahan), dibandingkan jika dijual langsung tanpa diolah terlebih dahulu. Nilai tambah home industry snack sayuran organik Jibariz, menggunakan metode Hayami (1987), perhitungan yang dilakukan pada satuan bahan baku utama dari produk hasil jadi. Melalui metode Hayami maka akan diketahui berapa besar distribusi dari nilai tambah akan tenaga kerja, jasa, dan keuntungan. Adapun hasil perhitungan nilai tambah home industry snack sayuran organik Jibariz, disajikan pada Tabel 2.
Berdasarkan tabel dari hasil penelitian, diketahui bahwa penggunaan bahan baku sebesar $10 \mathrm{~kg} /$ hari dengan faktor konversi 1,5, maka output yang dihasilkan dalam sekali produksi adalah $15 \mathrm{~kg}$ snack sayuran organik Jibariz. Nilai koefisien tenaga kerja pada proses produksi snack sayuran organik Jibariz sebesar 0,6 yang berarti bahwa kebutuhan dari input tenaga kerja sebesar $6 \mathrm{~kg}$ tepung, yang diolah menjadi stik dan pangsit menghasilkan nilai sebesar $0,6 \mathrm{HOK} / \mathrm{kg}$. Besaran harga rata-rata dari snack sayuran organik Jibariz adalah Rp. $50.000 / \mathrm{kg}$. Nilai tersebut diperoleh dari harga bahan baku utama sebesar Rp. $7.000 / \mathrm{kg}$. Nilai produksi snack sayuran organik Jibariz menghasilkan nilai tambah yang diciptakan Rp. 61.800 dengan skala $68,67 \%$. Hal ini dapat dikatakan bahwa persentase nilai tambah tersebut tergolong tinggi. Terdapat beberapa kriteria pengujian nilai tambah menurut Hermawatie (1998), yaitu rasio nilai tambah sebesar $<15 \%$ tergolong rendah, rasio nilai tambah $15 \%$ $40 \%$ tergolong sedang, dan rasio nilai tambah $.40 \%$ tergolong tinggi. Hasil penelitian ini sejalan dengan penelitian terdahulu yang dilakukan oleh Prasetiyo, et all (2018), yang menyatakan bahwa nilai tambah produk yang besarnya lebih dari $40 \%$ dapat dikategorikan sebagai nilai tambah yang tinggi.

Dari nilai tambah tersebut diperoleh imbalan tenaga kerja Rp. $8.000 / \mathrm{kg}$, dan bagian dari tenaga kerja $12,94 \%$ pada nilai tambah tersebut. Keuntungan yang didapatkan adalah Rp. 53.800 dengan tingkat keuntungan mencapai $59,77 \%$ dari nilai tambah yang dihasilkan. Menurut Asheri dan Amzul (2015), keuntungan akan berdampak positif bagi perusahaan apabila nilai tambah dari industri pengolahan bernilai semakin besar. Perhitungan margin diperoleh dari selisih harga produksi dikurangi bahan baku sehingga diperoleh margin sebesar Rp. 83.000. Persentase terbesar di dalam margin tersebut adalah pendapatan yang tenaga kerja 99,38\%, 
sedangkan persentase kedua terbesar adalah keuntungan yang didapatkan oleh pelaku usaha $64,8 \%$ dan persentase terkecil adalah sumbangan dari input lain $24,46 \%$, Hasil tersebut berbeda dengan penelitian sebelumnya oleh Hamidah (2015), dari hasil penelitiannya menunjukkan bahwa persentase keuntungan pengusaha lebih besar daripada pendapatan tenaga kerja dan sumbangan input lain.

Tabel 2. Hasil Perhitungan Analisis Nilai Tambah

\begin{tabular}{|c|c|c|c|}
\hline No & Variabel & \multirow[t]{2}{*}{ Notasi } & \multirow[t]{2}{*}{ Hasil } \\
\hline & Input, Output, Harga & & \\
\hline 1. & Hasil Produksi stik dan pangsit : (Kg/hari) & $\mathrm{A}$ & 15 \\
\hline 2. & Bahan Baku : tepung terigu (Kg/Hari) & B & 10 \\
\hline 3. & Tenaga Kerja (Jam/hari) & $\mathrm{C}$ & 6 \\
\hline 4. & Faktor Konversi $(1 / 2)$ & $\mathrm{d}=\mathrm{a} / \mathrm{b}$ & 1,5 \\
\hline 5. & Koefisien Tenaga Kerja (3/2) & $\mathrm{e}=\mathrm{c} / \mathrm{b}$ & 0,6 \\
\hline 6. & Harga Snack Jibariz (Rp/Kg) & $\mathrm{F}$ & 50.000 \\
\hline \multirow[t]{2}{*}{7.} & Upah Rata-Rata (Rp/hari) & $\mathrm{G}$ & 20.000 \\
\hline & \multicolumn{3}{|l|}{ Pendapatan dan Keuntungan } \\
\hline 8. & Harga Bahan Baku: tepung terigu $(\mathrm{Rp} / \mathrm{Kg})$ & $\mathrm{H}$ & 7000 \\
\hline 9. & Sumbangan Input Lain $(\mathrm{Rp} / \mathrm{Kg})$ & I & 21.2000 \\
\hline & Nilai Snack Jibariz $(\mathrm{Rp} / \mathrm{Kg})$ & $\mathrm{j}=\mathrm{dxf}$ & 90.000 \\
\hline & a. Nilai Tambah $(\mathrm{Rp} / \mathrm{Kg})$ & $\mathrm{k}=\mathrm{j}-\mathrm{h}-\mathrm{i}$ & 61.800 \\
\hline & b. Ratio Nilai Tambah $(\%)$ & $\mathrm{l}=(\mathrm{k} / \mathrm{j}) \times 100 \%$ & 68,66666 \\
\hline \multirow[t]{2}{*}{12.} & a. Imbalan Tenaga Kerja (Rp/Kg) & $\mathrm{m}=\mathrm{e} \times \mathrm{g}$ & 8000 \\
\hline & b. Bagian Tenaga Kerja $(\%)$ & $\mathrm{n}=(\mathrm{m} / \mathrm{k}) \times 100 \%$ & 12,94498 \\
\hline & a. Keuntungan $(11 a-12 a)$ & $\mathrm{o}=\mathrm{k}-\mathrm{m}$ & 53.800 \\
\hline & b. Tingkat Keuntungan (\%) & $\mathrm{p}=(\mathrm{o} / \mathrm{j}) \times 100 \%$ & 59,77777 \\
\hline & Balas Jasa untuk Faktor Produksi & & \\
\hline \multirow[t]{4}{*}{14.} & Marjin & $q=j-h$ & 83.000 \\
\hline & a.Pendapatan tenaga kerja $(\%)$ & $r=(\mathrm{m} / \mathrm{q}) \times 100 \%$ & 99,38554 \\
\hline & b. Sumbangan input lain $(\%)$ & $\mathrm{s}=(\mathrm{i} / \mathrm{l}) \times 100 \%$ & 244,61 \\
\hline & c.Keuntungan $(\%)$ & $\mathrm{t}=(\mathrm{o} / \mathrm{q}) \times 100 \%$ & 64,81927 \\
\hline
\end{tabular}

Sumber : Pengolahan Data Primer, 2021.

Hal ini menunjukkan bahwa pengusaha telah mencapai tingkat keuntungan usaha.

\section{Analisis Total Biaya, Penerimaan, dan Keuntungan \\ Analisis Biaya}

Berdasarkan pada Tabel 3, diperoleh biaya tetap berupa penyusutan peralatan setiap bulan sebesar Rp. 117.556. Biaya variabel berupa tenaga kerja dan bahan baku diperoleh sebesar Rp. 3.440 .000 sehingga total biaya keseluruhan Rp. 3.557.556. Pengeluaran terbesar adalah biaya tenaga kerja sebesar $28,11 \%$ hal ini dikarenakan dalam proses produksi minim menggunakan mekanisme mesin, dan upah tenaga kerja yang tinggi. Hasil penelitian ini sejalan dengan penelitian sebelumnya yang dilakukan oleh Yulianti dan Tinjung (2020), semakin tinggi upah tenaga kerja dan jumlah tenaga kerja dalam proses produksi maka semakin besar nilai peresentase yang diperoleh. Persentase biaya terbesar kedua adalah tepung terigu $19,68 \%$, karena merupakan salah satu bahan penunjang utama dalam proses produksi. Persentase biaya bahan baku penolong tertinggi adalah kentang 5,74\% karena varian rasa kentang 
pedas banyak diminati sehingga bahan tersebut banyak dibutuhkan dalam produksi, sedangkan bahan penolong terkecil adalah daun singkong $0,17 \%$ karena peminatnya kurang sehingga bahan tersebut tidak banyak dibutuhkan.

Tabel 3. Hasil Analisis Biaya

\begin{tabular}{|c|c|c|c|}
\hline No & Uraian Biaya & Jumlah & Presentase \\
\hline 1. & $\begin{array}{l}\text { Biaya Tetap/penyusutan } \\
\text { (Rp/bulan) } \\
\text { a. Alat (kompor, alat giling } \\
\text { adonan, sealer, stoples, } \\
\text { wajan, pisau, mixer, alat } \\
\text { pemotong } \\
\text { adonan,cobek,spatula, } \\
\text { blender,timbangan) }\end{array}$ & Rp. 117.556 & $3,31 \%$ \\
\hline 2. & $\begin{array}{l}\text { Biaya Variabel (Rp/bulan) } \\
\text { a. Pendapatan Tenaga Kerja } \\
\text { - Upah } \\
\text { - Jumlah Tenaga Kerja }\end{array}$ & $\begin{array}{c}\text { Rp. } 1.000 .000 \\
\text { Rp. } 500.000 \\
2\end{array}$ & $28,11 \%$ \\
\hline 3. & $\begin{array}{l}\text { b. Bahan } \\
\text { Tepung Terigu } \\
\text { Minyak Goreng } \\
\text { Gula Pasir } \\
\text { Garam } \\
\text { Margarin } \\
\text { Jagung Manis } \\
\text { Wortel } \\
\text { Ubi Ungu } \\
\text { Kentang } \\
\text { Labu } \\
\text { Bayam } \\
\text { Seledri } \\
\text { Brokoli } \\
\text { Sawi Pakcoy } \\
\text { Adas } \\
\text { Daun Singkong }\end{array}$ & $\begin{array}{c}\text { Rp. } 700.000 \\
\text { Rp. } 525.000 \\
\text { Rp. } 60.000 \\
\text { Rp. } 20.000 \\
\text { Rp. } 180.000 \\
\text { Rp. } 75.000 \\
\text { Rp. } 42.000 \\
\text { Rp. } 60.000 \\
\text { Rp. } 204.000 \\
\text { Rp. } 40.000 \\
\text { Rp. } 30.000 \\
\text { Rp. } 40.000 \\
\text { Rp. } 90.000 \\
\text { Rp. } 30.000 \\
\text { Rp. } 8.000 \\
\text { Rp. } 6.000 \\
\end{array}$ & $\begin{array}{l}19,68 \% \\
14,76 \% \\
1,69 \% \\
0,57 \% \\
5,06 \% \\
2,11 \% \\
1,19 \% \\
1,69 \% \\
5,74 \% \\
1,12 \% \\
0,84 \% \\
1,12 \% \\
2,52 \% \\
0,84 \% \\
0,22 \% \\
0,17 \% \\
\end{array}$ \\
\hline & $\begin{array}{l}\text { Total Biaya } \\
\text { (Rp/bulan) }\end{array}$ & Rp. 3.110 .000 & \\
\hline & $\begin{array}{l}\text { c. Kemasan (plastik,label) } \\
\text { d. Gas }\end{array}$ & $\begin{array}{l}\text { Rp. } 240.000 \\
\text { Rp. } 90.000\end{array}$ & $\begin{array}{l}6,74 \% \\
2,53 \%\end{array}$ \\
\hline & Total Biaya Variabel & Rp. 330.000 & \\
\hline 4. & Biaya Total (TC) & Rp. 3.557.556 & $100,00 \%$ \\
\hline
\end{tabular}

Sumber : Pengolahan Data Primer, 2021

Analisis Penerimaan, Keuntungan, dan Efisiensi Usaha
Penelitian ini membahas tentang penerimaan, keuntungan, dan efisiensi usaha dari total biaya home industry snack sayuran 
organik Jibariz, berdasarkan setiap harga yang berlaku pada saat penelitian berlangsung.

Tabel 4. Hasil Penerimaan, Keuntungan, dan Efisiensi Usaha

\begin{tabular}{llr}
\hline No & Uraian Biaya & Jumlah \\
\hline 1. & $\begin{array}{l}\text { Jumlah Produksi } \\
\text { (bungkus/bulan) }\end{array}$ & 600 \\
2. & $\begin{array}{l}\text { Harga per bungkus } \\
\text { (Rp) }\end{array}$ & 15.000 \\
3. & $\begin{array}{l}\text { Penerimaan } \\
\text { (Rp/bulan) }\end{array}$ & 9.0000 .000 \\
4. & $\begin{array}{l}\text { Keuntungan } \\
\text { (Rp/bulan) }\end{array}$ & 3.181 .000 \\
5. & R/C Ratio & 1,5 \\
\hline \multicolumn{2}{l}{ Sumber : Pengolahan Data Primer, (2021) }
\end{tabular}

Penerimaan yang diperoleh home industry snack sayuran organik Jibariz dalam satu bulan produksi dari harga jual per produk sebesar Rp. 15.000 dan menghasilkan 600 bungkus setiap bulan, maka total penerimaan yang diperoleh $\mathrm{Rp}$. 9.000.000. Menurut Arisandy, et all (2019), penerimaan dikatakan menguntungkan jika hasil dari nilai total penerimaan yang diperoleh lebih kecil daripada total biaya pengeluaran. Snack sayuran organik Jibariz setiap bulan meraup keuntungan sebesar Rp. 3.181.000. Efisisensi usaha dijadikan untuk mengetahui kondisi usaha layak atau tidak untuk dijalankan dan dikembangkan. Dari hasil perhitungan menunjukan $\mathrm{R} / \mathrm{C}$ ratio sebesar 1,5. Hal tersebut menunjukan masing-masing pengeluaran biaya sebesar Rp 1, maka akan memperoleh penerimaan sebesar Rp. 1,5. Home industry snack sayuran organik Jibariz, memiliki nilai R/C ratio 1,5 yang berarti usaha ini layak diusahakan atau dikembangkan. Hal ini sesuai dengan pendapat Suastina dan Kayana (2015), yang menyatakan bahwa usaha dapat dikatakan layak dijalankan apabila nilai $\mathrm{R} / \mathrm{C}$ ratio yang diperoleh lebih besar daripada 1 .

\section{Trend Perkembangan Usaha Home Industry Snack Sayuran Organik Jibariz}

Berdasarkan grafik pada Gambar 1, volume penjualan pada masa sebelum pandemi Covid-19 yaitu tahun 2018 hingga 2019, volume penjualan tertinggi terjadi pada bulan Juni 2018. Hal ini karena menjelang perayaan hari raya Idul Fitri permintaan semakin meningkat. Pada bulanbulan berikutnya volume penjualan cenderung mengalami fluktuasi. Faktor yang mempengaruhi hal tersebut adalah penjualan tertinggi hanya terjadi pada saat hari raya besar, setelah itu volume penjualan turun sehingga menyebabkan fluktuasi. Kenaikan atau penurunan pada jangka waktu selama periode menghasilkan pola data trend (Ajeng, 2011). Pergerakan garis pola data volume penjualan sebelum masa pandemi 2018 hingga 2019, menunjukkan garis trend penjualan yang mengalami penurunan. Menurut Maryati (2010), menyatakan bahwa trend merupakan pergerakan garis naik atau turun dalam jangka waktu lama, berdasarkan dari rata-rata perubahan volume dari waktu ke waktu. Hal tersebut terjadi karena pada titik grafik tertinggi yaitu pada bulan Juni 2018, apabila dihubungkan dengan titik terdekat kenaikan harga maksimum yaitu bulan Desember 2019, maka akan mengasilkan pergerakan fluktuasi pola data yang mengarah dari kanan ke kiri. Hasil tersebut berbeda dengan penelitian terdahulu yang dilakukan oleh Yanti et all (2016), dalam penelitian yang dilakukan trend penjualan kecap manis cenderung mengalami peningkatan karena pergerakan fluktuasi data mengarah dari kiri ke kanan. 


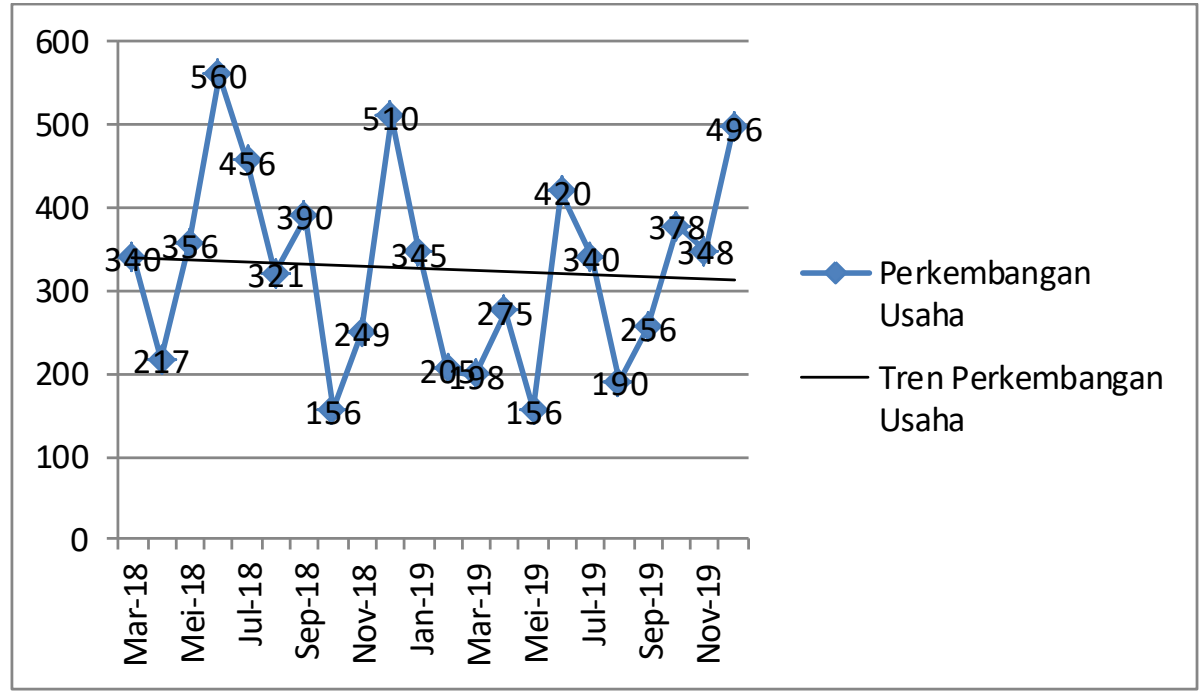

Gambar 1. Data Penjualan Jibariz Sebelum Pandemi Covid-19 Tahun 2018-2019

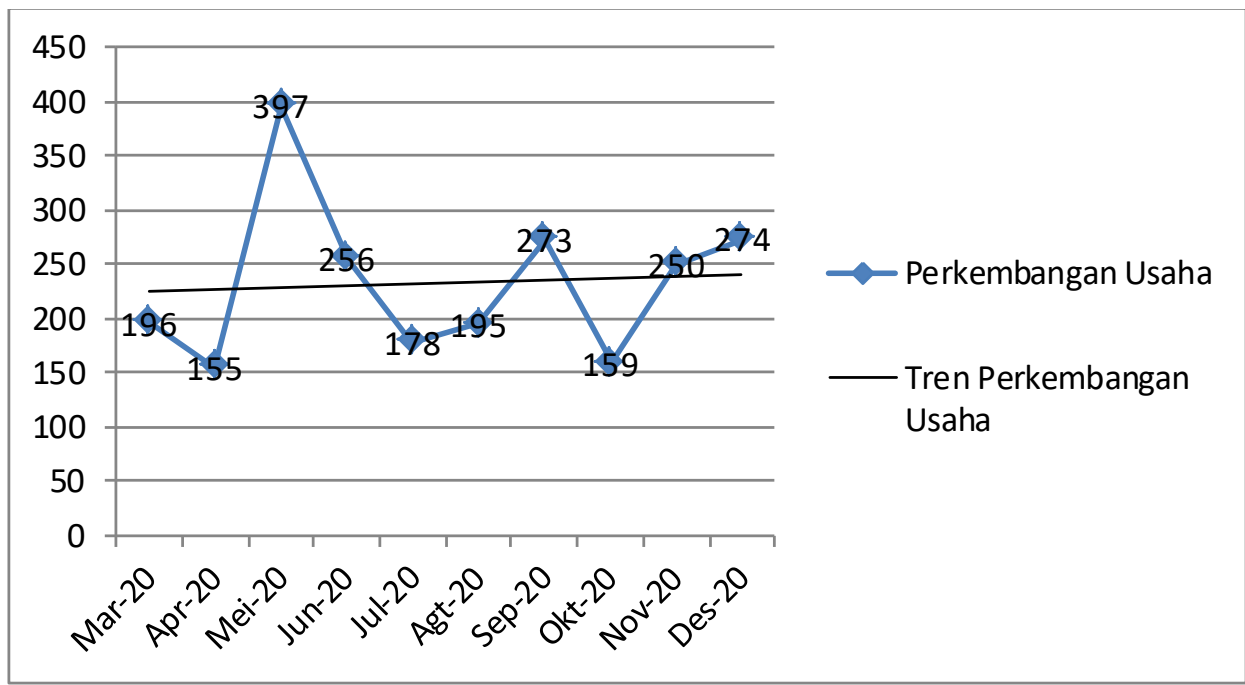

Gambar 2. Data Volume Penjualan Jibariz Sesudah Pandemi Covid-19 Tahun 2020

Berdasarkan grafik pada Gambar 2, dapat diketahui bahwa titik penjualan terendah terjadi pada bulan April yaitu sebesar 155 bungkus yang terjual. Hal ini disebabkan karena pada pembatasan Sosial Berskala Besar (PSBB) yang semakin diperketat oleh pemerintah, karena jumlah positif Covid-19 kian bertambah. Dalam upaya menekan jumlah penyebaran virus maka diterapkan pembatasan aktivitas, hal tersebut menyebabkan kerugian secara signifikan terhadap perekonomian nasional.
Berdasarkan pola data volume penjualan snack sayuran organik pada masa pandemi Covid-19 tahun 2020, trend perkembangan usaha mengalami peningkatan. Pada titik terendah yaitu bulan April apabila dihubungkan dengan titik terdekat maka pergerakan fluktuasi pola data mengarah dari kiri ke kanan. Faktor tersebut dipengaruhi oleh masyarakat yang mulai memiliki kesadaran terhadap pola konsumsi yang sehat. Mengkonsumi makanan sehat menjadi upaya dalam pencegahan dampak 
buruk dari virus dan menjaga daya tahan tubuh. Oleh sebab itu, di masa pandemi ini snack sayuran organik JIbariz dipilih sebagai alternative makanan sehat.

\section{Tanggapan Konsumen Terhadap Produk}

Pada penelitian ini, akan membahas tentang tanggapan konsumen terhadap minat beli produk meliputi kualitas rasa, pengemasan, dan keputusan pembelian. Kepuasan konsumen akan mempengaruhi terhadap perkembangan volume penjualan dan digunakan sebagai evaluasi produk. Berdasarkan pada Tabel 5, terdapat 5 orang konsumen snack sayuran organik Jibariz sebagai responden. Dari kelima responden rata-rata melakukan frekuensi pembelian sebanyak 2-6 kali dalam sebulan dan dalam satu kali pembelian rata-rata membeli 2-15 produk. Produk yang dibeli beraneka macam varian rasa tergantung dari selera atau produk favorit yang dipilih. Faktor rasa menjadi hal terpenting yang dijadikan sebagai pertimbangan dalam melakukan keputusan pembelian produk. Citarasa merupakan hal yang signifikan terhadap kepuasan konsumen (Maemunah, 2019). Hal terpenting yang menjadi pusat perhatian para konsumen adalah tampilan kemasan, karena kemasan yang memiliki keunikan akan menjadi daya tarik dan mempengaruhi konsumen dalam memilih produk tersebut (Kolter \& Keller,2013).

Tabel 5. Karakteristik Konsumen Snack Jibariz

\begin{tabular}{|c|c|c|c|c|}
\hline No. & Nama & Usia & Alamat & $\begin{array}{c}\text { Frekuensi } \\
\text { Pembelian } \\
\text { (bulan) }\end{array}$ \\
\hline 1. & $\begin{array}{l}\text { Agatha } \\
\text { Septiani }\end{array}$ & 23 & Salatiga & $6 \mathrm{kali}$ \\
\hline 2. & $\begin{array}{l}\text { Kesi } \\
\text { Lusiana }\end{array}$ & 29 & Salatiga & 5 kali \\
\hline 3. & Asih & 29 & Salatiga & 3 kali \\
\hline 4. & $\begin{array}{l}\text { Bintang } \\
\text { Adina }\end{array}$ & 24 & Semarang & 2 kali \\
\hline 5. & Titik & 50 & Banjarnegara & 2 kali \\
\hline
\end{tabular}

Sumber : Pengolahan Data Primer, 2021
Tanggapan dan masukan konsumen dalam segi rasa maupun pengemasan akan mempengaruhi dalam keputusan pembelian. Kepuasan konsumen akan mempengaruhi dalam pembelian ulang produk snack sayuran organik Jibariz. Berdasarkan hasil penelitian menunjukan bahwa, dalam segi rasa snack sayuran organik telah telah memenuhi harapan dan kepuasan konsumen sehingga mempengaruhi dalam pembelian ulang. Hal ini dibuktikan dengan frekuensi pembelian dari kelima responden lebih dari satu kali. Penelitian ini sejalan dengan penelitian sebelumnya yang dilakukan oleh Rahardjo (2016), yang menyatakan bahwa rasa menjadi faktor penting dalam evaluasi terhadap semua produk yang mereka konsumsi dalam mengetahui produk yang sesuai dengan prefensi dan kepuasan konsumen, sehingga mempengaruhi pembelian kembali. Dalam segi pengemasan konsumen merasa kurang puas karena kemasan tidak praktis dan desain label kurang menarik. Menurut Sukmawati (2018), Desain kemasan yang menarik sangat penting untuk performa sebuah produk agar meningkatkan percaya diri dalam bersaing dengan produk lain, dan sebagai daya tarik untuk memikat serta menjadi kepuasan konsumen terhadap produk yang dibeli.

\section{KESIMPULAN DAN SARAN}

\section{Kesimpulan}

1. Pengolahan snack sayuran organik yang dilakukan di dusun Jampelan, kecamatan Getasan, kabupaten Semarang, provinsi Jawa Tengah memperoleh nilai tambah yang tinggi yaitu sebesar Rp. 61.800 dengan ratio niali tambah $68,67 \%$.

2. Biaya total keseluruhan yang dikeluarkan oleh home industry snack sayuran organik Jibariz adalah sebesar Rp. 3.557.556, dengan jumlah produksi setiap bulan menghasilkan rata-rata 600 bungkus dan harga produk yang ditawarkan Rp. 15.000 per bungkus sehingga memperoleh penerimaan 
sebesar Rp. 9.000.000 serta memberikan keuntungan setiap bulan mencapai Rp. 3.181.000. Usaha snack sayuran organik Jibariz layak untuk dijalankan karena memiliki $\mathrm{R} / \mathrm{C}$ ratio $>1$.

3. Kondisi penjualan home industry snack sayuran organik Jibariz jika ditinjau melalui volume penjualan 2 tahun sebelum terjadi pandemi Covid-19 trend cenderung mengalami penurunan, sedangkan pada saat terjadi pandemi Covid-19 trend mengalami peningkatan.

\section{Saran}

1. Pemerintah dan penyuluh pertanian sebaiknya lebih memfokuskan pengolahan produk-produk pertanian yang memiliki nilai tambah, untuk menghimbau petani dalam mengatasi pendapatan rendah akibat harga yang turun saat panen raya.

2. Pemilik usaha snack sayuran organik sebaiknya membuat perbaikan pada kemasan produk terutama desain label, agar menambah nilai estetika dan memberi nilai tambah produk sehingga menjadi daya tarik konsumen.

3. Penelitian selanjutnya mengkaji lebih dalam terkait $\mathrm{B} / \mathrm{C}$ ratio dan manajemen pemasaran snack sayuran organik Jibariz.

\section{DAFTAR PUSTAKA}

Ajeng, S. (2011). Peramalan Penjualan Untuk Perencanaan Pengadaan Persediaan Buah Durian Di Rumah Durian Harum Bintaro Jakarta. Jakarta: Universitas Negeri Syarif Hidayatullah.

Ambarsari, W., V. D. Y. B. Ismadi, A. Setiadi. 2014. Analisis pendapatan dan profitabilitas usahatani padi (Oryza sativa, 1.) di Kabupaten Indramayu. Jurnal Agribisnis Wiralodra, 6(2), 19 - 27.
Arisandy, S. D., Jani, J., \& Joni M. M. A. (2019). Analisis Nilai Tambah Dan Perkembangan Usaha Agroindustri Asap Cair Tempurung Kelapa Pada CV Prima Rosandries Di Desa Kemiri Kecamatan Panti Kabupaten Jember. Jurnal Ekonomi Pertanian Dan Agribisnis, 3(2), 244-255.

Asheri, V. P., \& Amzul. (2015). Analisis Nilai Tambah Cokelat Batangan Chocolate Bar Di Pipiltin Cocoa Kebayoran Baru Jakarta Selatan. Jurnal Forum Agribisnis, 5(1).

Boediono. (2002). Ekonomi Makro: Seri Sinopsis Pengantar Ilmu Ekonomi. Yogjakarta: BPEE.

Ellyas, S. (2008). Pertanian Organik Solusi Hidup, Harmoni dan Berkelanjutan. Jakarta: Penebar Swadaya.

Hayami et., all. (1987). Agricultural Marketing and Processing ini Upland Java A Perspective From A Sunda Village. Bogor: CPGRT Centre.

Hermawatie. (1998). Agroindustri Tempe dan Peran Koperasi dalam Pengembangannya. Malang: Fakultas Pertanian Universitas Brawijaya.

Husniah, F. H., Triana D. H., \& Titin A. (2019). Analisis Nilai Tambah Agroindustri Kerupuk Tempe Kecamatan Puger Kabupaten Jember. Jurnal Ekonomi Pertanian Dan Agribisnis, 3(1), 195-203.

Kotler, P. \& Keller. (2013). Marketing Management fourteenth edition. London: Pearson Education.

Maemunah, S. (2019). Pengaruh kualitas pelayanan, persepsi harga, cita rasa terhadap kepuasan konsumen dan 
loyalitas konsumen.

IQTISHADequity 1(2), 57- 68.

Maryati. (2010). Statistika Ekonomi dan Bisnis, Edisi Revisi Cetakan Kedua. Yogyakarta: (UPP) AMPYKPN.

Prasetiyo, D. P., Abdul W. M., \& Silvana M. (2018). Analisis Nilai Tambah Nira Kelapa Pada Agroindustri Gula Merah Kelapa Kasus Pada agroindustri Gula Merah Desa Karangrejo Garum Blitar. Jurnal Ekonomi Pertanian Dan Agribisnis 2(1), 41-51.

Rahardjo, C. P. (2016). Faktor Yang Menjadi Prefensi Konsumen Dalam Membeli Produk Frozen Food. Jurnal Manajemen Dan Start Up Bisnis, 1(1).

Rosita, I. (2020). Pengaruh Pandemi Covid19 Terhadap Ukm Di Indonesia. Jurnal Lentera Bisnis, 9(2).

Soekartawati. (2003). Teori Ekonomi Produksi Dengan Bahasan Analisis Cobb Douglas. Jakarta: PT Raja Grafindo Persada.

Suastina \& Kayana. (2015). Susunan Rencana Usaha. Bali: Udayana.
Sugiyono, (2014). Metode Penelitian Pendidikan Pendekatan Kuantitatif, Kualitatif, dan R\&D. Bandung : Eidos.

Sujarweni, V. W. (2014). Metode Penelitian Lengkap, Praktis, dan Mudah Dipahami. Yogyakarta: Pustaka Baru Press.

Sukmawati D. A., \& Syafrial. (2018). Analisis Nilai Tambah Gula Kelapa Dan Strategi Pengembangan Pada Agroindustri Kecap Cap Srk Di Kabupaten Pacitan. Jurnal Ekonomi Pertanian Dan Agribisnis, 2(1), 2940.

Suratiyah, K. (2015). Ilmu Usahatani. Penebar Swadaya. Jakarta.

Yanti, N. P. L. P., Mahatma T., \& Agung S. W. (2016). Analisis Peramalan Penjualan Produk Kecap Pada Perusahaan Kecap Manalagi Denpasar Bali. Jurnal Rekayasa Dan Manajemen Agroindustri, 4(1), 7281.

Yuliawati T., \& Tinjung M. P. (2020). Analisis Usaha Dan Nilai Tambah Agroindustri Keripik Tempe Di Kedungjenar Kabupaten Blora Jawa Tengah. Jurnal Ekonomi Pertanian Dan Agribisnis, 4 (4), 88-892. 